\title{
"Stock Market Analysis and Investment Decision Making"-A Case Study Of Investors in North Karnataka Region
}

\author{
Amit B. Mirji ${ }^{1}$, Dr. Prashantha C. ${ }^{2}$ \\ ${ }^{1}$ (Research Scholar, Jain University, Bengaluru. India) \\ ${ }_{2}^{2}$ (Professor, Dept of Management Studies, SDM College of Engg \& Technology, Dharwad. India)
}

\begin{abstract}
Investment decision is of great significance as the process involves taking of risk for an anticipated return, stock market being highly volatile and unpredictable investors have to be careful in analyzing the market trend before committing their finds. Investors are inflamed by their own analysis and judgement of the stock market and the particular company whose shares are quoted on the stock market. Self analysis based on own judgement and experience and Brokers or friends who are involved in the investment and the media reports and reviews of stock market trends and the experts who have special knowledge about the stock market are the three sources of guidance for the investors in taking their investment decision. Preference for the self decision and advice of brokers has been indicial in case of investors with graduate and post-graduate level of education. However, investors with agricultural background have relied more on brokers, media analysis and experts option. Investors from business and employees have preferred their own decision and advice of brokers and friends. The general trend of investors' found from the study indicates that any are not heavily dependent on one source of stock market analysis in deciding their investment of time.
\end{abstract}

Keywords: Stock market, Investment decision, Investors, Brokers

\section{Introduction}

Investment decision is of great significance as the process involves taking of risk for an anticipated return. Stock market is known for its volatility and unpredictability as various factors affect the prospects of the market. Hence investors have to be careful in analyzing the market trend before committing their funds. Here investors are influenced largely by their own analysis and judgments of the stock market and the particular company whose shares are quoted on the stock market Self analysis based on own judgment and experience is largely relied upon by many investors. However many others rely on Brokers or friends who are involved in this line of investment for their guidance and opinion. A Third source which is relied upon in this context is the media reports and reviews of stocks market trends and the experts who have special knowledge about the stock market and their assistance is relied upon by a good number of investors.

\section{Source Of Guidance - Analysis}

The study covered 600 respondent investors in stock markets in selected district head quarters of North Karnataka region. The responses of the selected investors were obtained through a structural questionnaire relating to their sources of investment in the stock (i) self analysis (ii) Brokers and friends and (iii) Media / experts. The responses have been analyse taking into account the import and socio-economic profile of the respondent investors viz Sex, Age group, Education, Occupation, Annual income and years of experience in trading in the stock market. The statistical significance of the relationship of respondents' volume through the different source of guidance has been provided through chi-square test in each case.

It is significant to find that majority of 222 male investors made their own self decision of investment followed by 164 male investors who have availed of media analysis of the stock market and experts' opinion, while 96 male respondents depended on Brokers/friends analysis of the stock market while deciding on their respondents. However all the 118 women investors relied on Brokers/friends analysis while deciding investing in stock market, this shows a significant difference in the male and female investment behaviour.

Investors self analysis, Brokers and friends and media /friend analysis of the stock market have been relied upon by 149, 136 and 115 investor respondents in taking decision on their investments by those in the age group of 31-40 years. It shows that investors in this age group have relied on all the three major sources of stock market analysis in deciding their investment portfolio. An almost similar trend is found among those in the age group of 41-50 years, those in the age group of less than 30 years and those above 50years. Thus the investment decision of investors is influenced by more than one source of analysis by investors belonging to different age groups. Similarly self analysis of the stock market and the analysis made by Brokers/friends and Media/expert have been relied upon by majority of Graduate and Post-graduate investors covered by the study. There is no uniform pattern of decision making based on these three types of stock market analysis which influenced 
investment decisions of the respondent investors with different level of education. Brokers and self analysis have largely influenced the investment decisions of undergraduates and those few investors with business and employment as their occupation too have been depending on self analysis of the market and analysis made by Brokers/friends and Media/experts about the stock market while deciding their investment optima. A small number of respondent professional have depended on Brokers/friend, self analysis and Media/experts while deciding their investments. All the 12 home-makers have availed of the analysis of stock market by Brokers/friends while investors with agriculture as their occupation have relied on Brokers/friends and Media/experts in their investment decisions.

A similar trend of dependence equally on self analysis, Brokers/friends and Media/experts in investment activities in the stock market is indicated by majority 425 investors with annual income of Rs.500,001 to 100,000. Similar trend is observed among 118 investors with annual income of Rs $<=500000$ and 67 investors with annual income of Rs $>=1000001$

Maximum respondents of 415 investors with 6-10 years of experience of dealing in stock market had relied on all the three sources of stock market analysis with a relative majority of them depending on their self analysis of stock market for their investment activities. This trend is similarly found among 133 respondent investors in the 11+years of stock market experience and also in case of 52 respondent investors who depended relatively more on Brokers/friends and less on self and Media analysis of stock market for their investment decisions.

The analysis indicates that investors are not heavily dependent on one source of stock market analysis. However dependence on self analysis and Brokers' and friends is more pronounced with regard to investment decision making. The following table provides the details of Investment Decision Making - Sources of Guidance

Table No.1: Comparison of different characteristics and source of Guidance

\begin{tabular}{|c|c|c|c|c|c|c|c|}
\hline Characteristics & Self & $\%$ & Broker/friend & $\%$ & Media/expert & $\%$ & Total \\
\hline \multicolumn{8}{|l|}{ Sex } \\
\hline Male & 222 & 46.06 & 96 & 19.92 & 164 & 34.02 & 482 \\
\hline Female & 0 & 0.00 & 118 & 100.00 & 0 & 0.00 & 118 \\
\hline \multicolumn{8}{|l|}{ Age groups } \\
\hline$<=30$ yrs & 8 & 19.51 & 23 & 56.10 & 10 & 24.39 & 41 \\
\hline 31-40yrs & 149 & 37.25 & 136 & 34.00 & 115 & 28.75 & 400 \\
\hline $41-50 y r s$ & 60 & 42.55 & 49 & 34.75 & 32 & 22.70 & 141 \\
\hline$>=51 \mathrm{yrs}$ & 5 & 27.78 & 6 & 33.33 & 7 & 38.89 & 18 \\
\hline \multicolumn{8}{|l|}{ Educations } \\
\hline Undergraduate & 8 & 17.39 & 22 & 47.83 & 16 & 34.78 & 46 \\
\hline Graduate & 120 & 47.62 & 56 & 22.22 & 76 & 30.16 & 252 \\
\hline Post graduate & 90 & 30.61 & 132 & 44.90 & 72 & 24.49 & 294 \\
\hline Doctorate & 4 & 50.00 & 4 & 50.00 & 0 & 0.00 & 8 \\
\hline \multicolumn{8}{|l|}{ Occupations } \\
\hline Agriculture & 0 & 0.00 & 6 & 50.00 & 6 & 50.00 & 12 \\
\hline Business & 108 & 46.15 & 58 & 24.79 & 68 & 29.06 & 234 \\
\hline Employee & 106 & 34.19 & 122 & 39.35 & 82 & 26.45 & 310 \\
\hline Home worker & 0 & 0.00 & 12 & 100.00 & 0 & 0.00 & 12 \\
\hline Professional & 8 & 25.00 & 16 & 50.00 & 8 & 25.00 & 32 \\
\hline \multicolumn{8}{|l|}{ Annual income } \\
\hline$<=500000$ & 36 & 33.33 & 46 & 42.59 & 26 & 24.07 & 108 \\
\hline $500001-1000000$ & 164 & 38.59 & 135 & 31.76 & 126 & 29.65 & 425 \\
\hline$>=1000001$ & 22 & 32.84 & 33 & 49.25 & 12 & 17.91 & 67 \\
\hline \multicolumn{8}{|c|}{ Years on stock market } \\
\hline $1-5 y r s$ & 14 & 26.92 & 30 & 57.69 & 8 & 15.38 & 52 \\
\hline $6-10 y r s$ & 153 & 36.87 & 133 & 32.05 & 129 & 31.08 & 415 \\
\hline $11+\mathrm{yrs}$ & 55 & 41.35 & 51 & 38.35 & 27 & 20.30 & 133 \\
\hline Total & 222 & 37.00 & 214 & 35.67 & 164 & 27.33 & 600 \\
\hline
\end{tabular}

Table No.2: Comparison of different characteristics by chi-square test

\begin{tabular}{|l|l|l|}
\hline Characteristics & Chi-square & p-value \\
\hline Sex & 264.9470 & $0.0001^{*}$ \\
\hline Age groups & 12.5680 & $0.0500^{*}$ \\
\hline Educations & 42.9570 & $0.0001^{*}$ \\
\hline Occupations & 47.4360 & $0.0001^{*}$ \\
\hline Annual income & 11.1590 & $0.0250^{*}$ \\
\hline Yrs on stock market & 18.2330 & $0.0010^{*}$ \\
\hline
\end{tabular}

$* \mathrm{p}<0.05$ 
“Stock Market Analysis and Investment Decision Making”-A Case Study of Investors in North ....

1) The association between sex and source of decision for stock market is found to be statistically significant (Chi-square $=264.94, p=0.0001)$ at $5 \%$ level of significance.

2) A significant association between age groups and source of decision is found to be statistically significant( Chi-square $=12.56, \mathrm{p}=0.0001$ )at $5 \%$ level of significance.

3) The difference between education and types of Cap is found to be statistically significant( Chisquare $=42.95, \mathrm{p}=0.0001$ ) at $5 \%$ level of significance.

4) The association between annual income and investor analysis for stock market is found to be statistically significant (Chi-square $=47.43, \mathrm{p}=0.0001)$ at $5 \%$ level of significance.

5) A significant association between annually income and investor analysis for stock market is found to be statistically significant (Chi-square $=11.159, \mathrm{p}=0.0250)$ at $5 \%$ level of significance.

6) Lastly, a significant association was observed between years on stock market and investor analysis for stock market is found to be statistically significant (Chi-square $=18.233, \mathrm{p}=0.0010)$ at $5 \%$ level of significance.

\section{Conclusion}

The analysis of the responses of the investors indicates that there is no heavy dependence on one source of stock market analysis for investment decisions. However dependence on self analysis and on Brokers/ friends is more pronounced with regard to investment decisions by the respondent investors in the study area. It is significant to note that the different profile characteristics of the investors indicate greatest reliance on self analysis and on analysis of stock by Broker/ friends by majority of respondents in the age groups of 31-40 years those with graduate and post graduate level of education, investors occupied in business and employment, investors with annual income level of Rs $<=500000$ and $\mathrm{Rs}=500001-10,00,000$ and investors with 6-10 years and $11+$ years of stock market experience.

\section{References}

[1] Chandra Abhijeet (2008)-Decision Making in the stock market-Incorporating psychology with Finance -Department of commerce and Business studies-New Delhi.

[2] Hoffman, Arivd O,I, Shefrin Hersh and Pnnings Joost MF (2010)-Behavioural portfolio Analysis of Individual Investors- working paper Maastricht University and Junta Clara University .

[3] Subrahmanyam Avanidhar (2007)- Behavioural Finance :A Review and Synthesis -European Financial Management 14(1):12-29.

[4] Subash R(2012)-Role of Behavioural Finance in Portfolio Investment Decisions: Evidence from India-Master Thesis, Faculty of social sciences, charle University Prague,2012.

[5] Pompian,M.(2011)-Behavioural Finance and wealth Management: How to Build optimal portfolios. That Account for Investor Bases, $2^{\text {nd }}$ Edition Wiley Finance publication, New Jersey 2011.

[6] Statman .M. (1999)-Behavioural Finance : past Battles and Future Engagements ,Finance Analysis Journal vol 55 no 6 ,

[7] Statman .M. (2008)-what is Behavioural Finance Hand book of Finance -vol, II, John wily and sons Inc, New Jersey 2008

[8] Shefrin H (2008)-Beyand Greed and Fear: Understanding Behavioural Finance and the psychology of investing -New York

[9] Chandra .A.(2008)-Decision Making in Stock Market - Incorporating Psychology with Finance : Department of commerce and Business Studies.

[10] Banerjee Arindam(2011)-Application of Behavioural Finance in Investment Decision -An overview - The Management Accountant 46(10).

[11] Chen et al (2007) trading performance disposition Effect over confidence Representativeness Bias and experience of emerging Market Investors SSRN working paper 2007

[12] Pompeian Michaud (2006) Behavioral finance and Wealth Management USA John Willer and sons. 